\title{
"A phony way to show sincerity, as we all well know": tobacco industry lobbying against tobacco control in Hong Kong
}

\author{
J Knight, S Chapman
}

Tobacco Control 2004;13(Supp II):ii13-ii21. doi: 10.1136/tc.2004.007641

See end of article for authors' affiliations

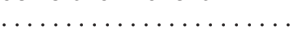

Correspondence to: Dr Jennifer Knight, School of Public Health, Room 129A, Edward Ford Building (A27), University of Sydney, Sydney, NSW 2006, Australia; knighti@ health.usyd.edu.au

\begin{abstract}
Objective: To examine the tobacco industry's efforts to influence public policy and block the legislative process on tobacco control in Hong Kong, 1973 to 1997.

Method: Systematic review of relevant tobacco industry documents made public via the Master Settlement Agreement.

Results: The tobacco industry in Hong Kong has sought to manipulate the policymaking process and delay the introduction of tobacco control legislation in Hong Kong from at least 1973. The industry ensured that each of the government's initial meagre steps toward tobacco control were delayed and thwarted by drawn out "cooperation" followed by voluntary concessions on issues the industry regarded as minor. By the 1980s the government had became increasingly active in tobacco control and introduced a number of initiatives, resulting in some of the tightest legislative restrictions on smoking in Asia. The tobacco industry was successful in thwarting only one of these initiatives.

Conclusions: Throughout the 1980s and 1990s two factors played a significant role in hindering the tobacco industry from successfully blocking policy initiatives: a growing political imperative, and an active and sophisticated tobacco control movement. Political will to promote public health and a strong tobacco control advocacy presence can enable governments to resist the enormous pressure exerted upon them by multinational tobacco companies.
\end{abstract}

$\mathrm{H}$ ong Kong (HK) entered the new millennium with a strong and broad ranging tobacco control policy designed "to discourage smoking, contain the proliferation of tobacco use and protect the public from passive smoking...". Smoking prevalence among adults in HK is currently $25 \%$ (men) and $4 \%$ (women), ${ }^{2}$ one of the lowest rates in the region. Today, all print and display tobacco advertising is banned, smoking is banned in virtually all public areas (hospitals, schools, department stores, shopping malls, supermarkets, banks, cinemas, and public transport); the sale of cigarettes through vending machines is prohibited; one third of seating in large restaurants has to be nonsmoking. However, this degree of tobacco control has not always characterised HK. Throughout the 1970s the tobacco industry was comforted by its perception that the government took "a backseat" ${ }^{\prime 3}$ on the issue and that it was able to block initial tobacco control initiatives with relative ease.

This paper reviews the tobacco industry's efforts to manipulate and pressure the HK government to minimise tobacco control. Action taken in HK was significant: industry, for example, considered it "a mirror of the region and ... a trend setter for China"4 and "a showcase to support the PRC [People's Republic of China] business".

HK was not the first country to experience interference from the tobacco industry. Industry's attempts to stymie legislation and interfere with the policymaking process at the regional (European ${ }^{6}$ and South America ${ }^{7}$ ), national (for example, Germany, ${ }^{8}$ Australia, ${ }^{9}$ Thailand, ${ }^{10}$ Hungary, ${ }^{11}$ Malaysia $^{12}$ ) and local state level ${ }^{13}{ }^{14}$ are well documented. Many of the tactics used in these examples found their way to HK.

\section{METHOD}

This study is based on material contained in recently released internal tobacco industry documents. Key words utilised in searches of both tobacco industry and non-industry websites included "Hong Kong", "Tobacco Institute of Hong Kong", "Health + Welfare Branch", "COSH", ExCo", "LegCo", as well as the names of key individuals identified in relevant documents. Although all relevant tobacco industry websites were searched, the Philip Morris (www.pmdocs.com) and Tobacco Documents Online (http://tobaccodocuments.org) websites provided most of the relevant documents. Overall, 190 relevant documents were retrieved and this paper presents an annotated chronology of the more significant revelations thus located. Further details of search procedures can be found in http://tobacco.health.usyd.edu.au/site/ gateway/docs/pdf/HongKong.pdf.

\section{RESULTS}

HK was a British colony from 1842-1997. Its parliamentary system and legislative process over this time reflected many of the traditions and practices of the British Westminster parliamentary system. The primary agencies in the political process, together with the leading tobacco and tobacco control interest groups, are identified in table 1.

The HK political process involved two key attributes which the tobacco industry used to its advantage when pressuring the government to stall or abandon policy initiatives. First, HK featured a vigorous public consultation process whereby the public and business community could express opinion and advocate positions for government consideration as legislation was prepared. This strong consultation tradition provided the tobacco industry with many opportunities to

Abbreviations: B\&W, Brown \& Williamson; BAT, British American Tobacco; BRB, Broadcasting Review Board; COSH, Council on Smoking and Health; DBs, District Boards; HK, Hong Kong; LegCo, Legislative Council; PRC, People's Republic of China; RJR, RJ Reynolds; TAHK, Television Authority of Hong Kong, TIHK, Tobacco Institute of Hong Kong 
Table 1 Major agents involved in the Hong Kong tobacco control process (pre-1997)

\begin{tabular}{|c|c|}
\hline Agent & Role \\
\hline Governor & $\begin{array}{l}\text { The British Crown's representative } \\
\text { holding vice-regal powers. }\end{array}$ \\
\hline Legislative Council (LegCo) & $\begin{array}{l}\text { The sole chamber of the HK parliament } \\
\text { comprising both appointed and elected } \\
\text { members }\end{array}$ \\
\hline Executive Council (ExCo) & $\begin{array}{l}\text { Government's inner circle responsible } \\
\text { for determining and controlling policy }\end{array}$ \\
\hline District Boards (DBs) & $\begin{array}{l}\text { Played an important role in the } \\
\text { policymaking process by holding public } \\
\text { forums and providing the opportunity } \\
\text { for local constituents to express their } \\
\text { views on a range of policy initiatives } \\
\text { Each board was headed by a chairman }\end{array}$ \\
\hline Asian Tobacco Council (ATC) & $\begin{array}{l}\text { Established by industry in } 1990^{17} \text { and } \\
\text { based in HK }\end{array}$ \\
\hline $\begin{array}{l}\text { Council on Smoking and } \\
\text { Health (COSH) }\end{array}$ & $\begin{array}{l}\text { Established and funded by the } \\
\text { government in } 1987 .{ }^{18} \text { Its role included: } \\
\text { informing and educating the public } \\
\text { on the harm of smoking } \\
\text { conducting and coordinating } \\
\text { research } \\
\text { advising the government on } \\
\text { smoking/health matters }\end{array}$ \\
\hline $\begin{array}{l}\text { Tobacco Institute of Hong } \\
\text { Kong (TIHK) }\end{array}$ & $\begin{array}{l}\text { HK based tobacco lobby group } \\
\text { established in } 1983 \text {. Replaced the Hong } \\
\text { Kong Tobacco Industry Association }\end{array}$ \\
\hline
\end{tabular}

obstruct and pressure the legislature. District Boards (DBs) played a pivotal role in this process. The tobacco industry placed great emphasis on winning the support of board chairs and speaking to the boards.

Second, this consultation process required considerable time. Government announced intended policy change and then invited public comment for up to six months. This input would sometimes be summarised and released as publications. Legislation would then be prepared and proceed through the parliamentary process, including committees. The time involved here was fully exploited by the industry. They had time to include other interested parties in lobbying activities and to conduct purposive surveys and publicise the results, which invariably suggested the policy proposals were unpopular. ${ }^{15}$ Attributes such as these led Clive Turner of the Asian Tobacco Council to observe wryly that in HK "nothing happens overnight". ${ }^{16}$

\section{Tobacco control in the 1970 s}

During the 1970s tobacco control in HK was ad hoc and uncoordinated. Companies described government policy during the decade as one of "non intervention"20 and suggested that government had "adopted a policy of laissez-faire" ${ }^{\prime 21}$ on smoking with the result that "there are almost no restrictions in the Colony". ${ }^{21}$ A Philip Morris International memo succinctly summarised the situation over this period:

\footnotetext{
"Present legislation does not impose any restriction whatever on cigarette advertising... no organised campaign was ever conducted... against smoking... all cigarette advertisements can be placed in any mass medium... local cigarette manufacturers... adopt an attitude of "least said, the better". ${ }^{21}$
}

Industry influence on policy followed the "give an inch to gain a decade" principle: "by opening a dialogue, followed by a few minor concessions, the industry can be saved from heavy legislation for at least $2 / 3$ more years". ${ }^{3}$

The key governmental tobacco control initiative during this period was the formation of an Ad Hoc Committee on Smoking and Health in 1973. The objectives of the committee were very limited, having no formal terms of reference. Industry anticipated the outcomes would not "be controversial or... involve significant expenditure or require legislation". ${ }^{22}$

The industry was invited to appear before the committee and they invested considerable time, ${ }^{23-25}$ and effort $^{26-28}$ preparing for the hearing. They decided among themselves that "the over-riding policy should be to discourage and delay the process of restrictive legislative action... in every way possible". ${ }^{26}$ One potential concession debated was the voluntary withdrawal of television and radio advertising during afternoons and early evening conceding that:

"This is one of the proposals that we shall initiate to show that we as an industry are doing something about discouraging young people to smoke. This of course is a phony way of showing sincerity as we all well know ${ }^{\prime \prime}{ }^{23}$

Agreement was reached between industry and the committee for such a code. Industry was delighted with the outcome claiming government "seem to be positively inclined towards the industry's views rather than anti the industry". ${ }^{29}$ When released, the committee's report included recommendations on smoking and youth, cigarette advertising, increasing public awareness and smoking in public places. ${ }^{30}$

No action was taken on the report until 15 months later when the Television Authority of Hong Kong (TAHK) began developing the recommended voluntary code. Government immediately turned to industry for their input. In response, British American Tobacco (BAT) suggested it was advisable to cooperate with the authority to avoid a situation where "undesirable legislation is imposed upon us". ${ }^{31}$ Industry unanimously agreed that "dialogue was preferable to imposed legislation". ${ }^{32}$

Early in the negotiation process TAHK assured industry representatives that "the government was not treating the smoking and health question... as a priority area". ${ }^{33}$ Industry/ TAHK discussion were such that Falconer (Philip Morris $(\mathrm{PM})$ ) concluded that the government:

\footnotetext{
"is not really very keen to hammer the industry on this matter but neither can they bury their head... I envisage that we will propose a code of practice that is extremely weak and centers around those areas that we really do not use at the moment... personally I do not believe that the proposed restrictions will in anyway hurt our business for many years after that ${ }^{\prime \prime}{ }^{33}$
}

Throughout 1976 industry invested energy into getting the code's wording just right. In a memo from Pethebridge (BAT) to Wong (RJ Reynolds (RJR)), for example, Pethebridge stated:

\begin{abstract}
"Mr Bolsover [BAT] is concerned that our revised draft is a bit too wishy washy and does not include enough 'teeth' for Oliphant [TAHK]. He is afraid that we could be accused... of a lack of co-operation in that we are proposing nothing very new or constructive, in content terms. We must appear to be responsibly co-operative, especially if we wish to avoid legislation. ${ }^{\prime \prime 34}$
\end{abstract}

The code was introduced in 1977 and remained in place until superseded by legislation introduced in 1982 and 1988. The industry's willingness to introduce a self regulating code 
paid off handsomely. In early 1977 the government announced that it would not be pursuing the Ad Hoc Committee's recommendations on cigarette advertising or health warnings. PM was delighted: "it would appear that the industry's lobby to government, together with their sensible approach to... a voluntary code for television, has paid dividends". ${ }^{35}$

Two years later, a second committee recommendation on public information was implemented. Posters stating "Smoking endangers your health" began appearing on public transport, ${ }^{36}$ blindsiding the industry. Their concern centred on the lack of notification, the absence of any government attribution on the poster, use of the red, international "No Smoking" symbol, and the strong wording. ${ }^{37}{ }^{38}$ To RJR this development was "potentially very dangerous were it allowed to get out of hand". ${ }^{20}$

Following a salvo of letters of complaint about the posters, ${ }^{37-39}$ the government buckled and agreed to their redesign $^{40}$ and that any further efforts would carry a government attribution if the dangers of smoking were mentioned. ${ }^{41}$ The re-designed posters were smaller; the international symbol was removed; the wording was less offensive to the industry; and the claim was attributed to the government.

Toward the end of the decade RJR advised its head office:

\section{"There has been no formal government position taken on any aspect of the smoking issue-be it health or social oriented... we are very fortunate in Hong Kong to date, in our relative freedom to act. We have no doubt that further restrictions will be imposed on the industry. The only question is when". ${ }^{\prime 2}$}

BAT made similar comments to its headquarters: "smoking and health issue in Hong Kong has not yet developed to the extent that it has in Europe and North America". ${ }^{43}$

\section{The 1980s: striving for "more breathing space"}

Unlike the previous decade, the 1980s was a time of significant change in $\mathrm{HK}$ as the government began to realise the health and social costs of smoking. Mackay identified three factors that "influenced government" 45 in the early 1980s: health (actual deaths from lung cancer increased by $92 \%$ from 1972 to $1982^{45}$ ); fires and accidents (one in three reported fire accidents were caused by careless smoking ${ }^{45}$ ); and public opinion (75\% of respondents to an extensive 1981 survey were in favour of banning smoking on public transport and enclosed public spaces ${ }^{45}$ ). The government responded by introducing a series of initiatives that placed tobacco control firmly on the public policy and legislative agenda.

As the tempo of government intervention increased, the industry responded accordingly. Regional industry offices set up corporate affairs departments responsible for devising and implementing strategic plans. ${ }^{46}$ Public relations firms were engaged to conduct a broad range of lobbying activities and an industry association was formed. The broad purpose of all these initiatives was to obstruct government policy and portray the industry favourably to the public.

During 1980 the government initiated a five point programme which sought to impose new regulations in areas including: bans on smoking in enclosed places (including public transport); warning statements and yield contents on cigarette packs and advertising; tar and nicotine testing and publication; phased extension of media advertising bans; and increased public education ${ }^{47}$ These proposals were informally presented to industry ${ }^{48}$ along with the suggestion industry respond prior to the package being submitted to ExCo. ${ }^{47}$ In framing their response, Wisner (Brown \& Williamson $(\mathrm{B} \& \mathrm{~W}))$ believed the objective was "to keep these to a bare minimum by playing on their reasonableness". ${ }^{49}$

Industry was active in all stages of the legislative process. The documents, however, reveal that what industry was saying publicly didn't match what they thought privately. Among themselves, industry was delighted with the drafting instructions for the Bill which they felt "reflect[ed] many of the points" ${ }^{\prime 50}$ they had raised resulting in the revisions being "more consistent with our interests". ${ }^{50}$ Publicly though industry objected strongly to the proposals, considering them to be "more extreme" than expected and to "violate the spirit of the government's philosophy of free trade". ${ }^{51}$ They also urged "restraint", considering it "an unprecedented intrusion of government to impose many of these restrictions" ${ }^{51}$

The Public Health Bill covering each of the points originally outlined to industry passed through the Legislative Council (LegCo) in 1982 (see Mackay and Barnes ${ }^{52}$ for reforms). As the Colony's first statutory base for non-smoking measures it represented the government's initial attempt at an antismoking policy with provision for a major anti-smoking campaign. ${ }^{45}$ 53-55

Despite the industry's involvement in the formation of the legislation they expressed their disappointment, claiming it represented an "abrupt departure from the traditional role government has played in the Colony's commerce". ${ }^{56}$ However, they chose not to issue any media releases and to be "non-antagonistic and avoid ruffling any feathers within the government". ${ }^{57}$

Their muted response may well have reflected their lack of concern at the impact of the legislation. They felt the campaign "lack[ed] real seriousness and long-term viability $^{\prime \prime 58}$ and the effect of the campaign and legislation was "minimal" as the campaign was "a 'guilo' [western] issue - a white man's one" conducted by "career activists [who] ...jump from one popular issue to the next and most likely will tire of this one soon". ${ }^{59}$

In 1983, responding to a budgetary deficit, the government announced duty increases on imported liquor and tobacco of up to $300 \%$. The move was seen by the industry as "the greatest blow to the trade". ${ }^{.9}$ Although tobacco companies absorbed part of the increase, retail prices of cigarettes increased within weeks. Sales dropped so drastically that tobacco companies cut prices again the following month. ${ }^{59}$ Industry desperately and unsuccessfully sought the cooperation of the US State Department to have the tax rescinded. ${ }^{60}$

By the end of $198395 \%$ of the population were not only aware of the government's publicity campaign but also believed smoking was harmful. ${ }^{52}$ The government's initiatives impacted significantly on the nation's smoking population. From 1982 to 1984 the number of people who smoked daily fell by $16 \%$ while the number of teenage smokers over the same period halved. ${ }^{52}$ As Mackay and Barnes accurately observed at the time:

Political action, with support, funding and protection by the government, in a developing Asian country can have striking effects upon cigarette smoking and awareness in the community of the dangers of tobacco. The success of the campaign in HK was largely due to such government action. ${ }^{52}$

In what Mackay and Barnes consider to be a sign of the campaigns' "success", 52 industry established the Tobacco Institute of Hong Kong Ltd (TIHK) in 1983. The aims of the institute included the promotion of "measures calculated to benefit and protect the interests of the tobacco industry in Hong Kong". ${ }^{52}$ 
In 1984 the government announced a public inquiry into the licensing terms of the country's two main television stations to be conducted by the Broadcasting Review Board (BRB). One of the inquiry's terms of reference called for "consideration of the change required in the conditions of advertising control with a view to the possibility of banning certain types of advertisement..." ${ }^{61}$

The first major task of the TIHK was to facilitate the industry's internationally coordinated response to the inquiry (prepared with the assistance of INFOTAB $^{62}$ ). In January 1985 a "veritable army" ${ }^{\prime 52}$ of industry representatives appeared before the BRB. ${ }^{63-67}$ At the instigation of local tobacco control interest groups, an international contingent of experts supporting controls on advertising also appeared before the board.

The final BRB report recommended a total ban on all forms of tobacco advertising on television and radio. ${ }^{61}$ Following its tabling, a six month period of public consultation followed. The industry was conscious of the opportunity this offered them to ensure the recommendation was overwhelmingly rejected by the public. To achieve this, the industry implemented a multi-faceted and sustained campaign which included paid advertisements in the press, and the use of influential local groups such as newspapers, advertising agencies, friends in the business community, and the television stations themselves. ${ }^{68}$

The government did not always facilitate the industry's efforts. It prohibited, for example, the industry from airing a series of commercials supporting their position claiming that any advertisement that sought to "change or to prevent a change in the law is legally defined as political" and thus prohibited. ${ }^{69}$ The TIHK framed the ban as "government interference", ${ }^{69}$ and was supported by the country's two English language newspapers. ${ }^{69}$ PM responded with a number of strategies to counter the bans including:

\section{"integrate the issue with the government's policy of freedom of choice and free enterprise; lobby the executive councilors, legislative councilors, district board members and relevant government bodies; generate petitions... ; increase the impact of Marlboro's outdoor advertising... develop alibi advertising..." ${ }^{70}$}

The report prepared at the conclusion of the public consultation process documented the industry's lobbying achievements, with the majority of submissions to the government opposed to a total ban on tobacco advertising. ${ }^{71}$ The report noted that "few reports of a similar nature have aroused so much debate" ${ }^{\prime \prime} .^{71}$

The industry used evidence of this overwhelming opposition to pressure ExCo to stand by a criterion set by the Governor-that the recommendations of the BRB must be "acceptable to the community as a whole". ${ }^{72}$

Despite the industry campaign, ExCo announced its decision in November 1988 to ban tobacco advertising on television and radio from December 1990, along with a raft of restrictions that were to take effect almost immediately.

Having failed to influence government, industry determined to stall the introduction of the proposals. It solicited the support of the Association of Accredited Advertising Agents of Hong Kong who met with government "to have the revision delayed as long as possible" ${ }^{\prime 44}$ and investigated the possibility of having the decision overturned. This option was dropped when their legal advice suggested an open challenge to ExCo would prompt the latter into formalising restrictions through legislative means "thereby opening the floodgate to other forms of restrictions other than the electronic media" ${ }^{\prime 4}$ — something the industry was anxious to avoid.
The government established and funded a Council on Smoking and Health (COSH) in 1987. ${ }^{18}$ The first major work of COSH was a consultation paper released in March 1989. The paper contained recommendations for government action in seven areas. The 24 recommendations set the agenda for an industry determined to thwart all attempts by the government to implement further tobacco control.

Documents from this period attest to industry's determination: "the major task faced by the industry in 1989/90 was how to forestall the 24 recommendations put forward by $\mathrm{COSH}^{\prime},{ }^{73}$ and "it is essential that we defeat or substantially water down the COSH proposals in Hong Kong to ensure that it [COSH proposal] is not used as a precedent for the region" ${ }^{46}$

A public relations company was hired by TIHK to implement a lobbying programme ${ }^{74}$ ranging from establishing the attitudes of the new Governor to exploiting LegCo members "who can provide inside information". ${ }^{74}$ A submission responding to each recommendation was prepared ${ }^{75} 76$ with its covering letter noting:

\section{"These extreme $\mathrm{COSH}$ proposals indicate a manipulative approach to society and over-stressing of government's role in society which is often termed "social engineering". It is the moulding of "acceptable" behaviour in one's own image of what social conduct should be ...". ${ }^{77}$}

Again, the industry sought to influence the public consultation process that would follow the release of the $\mathrm{COSH}$ consultation paper. Strategy was coordinated by TIHK's Brenda $\mathrm{Chow}^{73}$ and included speeches on advertising freedom to Rotary clubs, press releases and conferences, letters to newspapers, requests to DBs to attend their meetings, and an extensive mailing campaign, with some 1500 letters being sent. ${ }^{78}$ Other strategies included the formation of a coalition with the restaurant industry and, in response to industry's "major" concern $^{73}$ with proposed further advertising and sponsorship restrictions, extensive lobbying of DB members, arts and sports groups. These latter activities "generated overwhelming support for the industry" ${ }^{\prime 73}$ leading to speculation that it would be "unlikely that the government would proceed with the proposed bans" ${ }^{\prime 7}{ }^{73}$ As an additional measure, the industry agreed on yet another self regulatory code for advertising and sponsorship. ${ }^{73}$ Any progress anticipated by the industry as a result of these strategies was to be very short lived.

\section{The 1990s: "doing a deal with government"/79}

The government entered the new decade apparently buoyed by their achievements in tobacco control in the previous decade and ready to build upon those successes. In the first three years, they introduced three substantial initiatives. In March 1990 the government announced its response to the COSH proposals and the ensuing public consultation process. Plans to ban smoking on all forms of public transport as well as in cinemas, theatres, concert halls and video game centres were announced. ${ }^{80}$ Tighter restrictions on tobacco advertising and rotating health warnings were also to be introduced, along with upper limits on the tar and/or nicotine content of cigarettes. $^{80}$

Once again the industry sought to influence the process of formulating legislation, meeting with the government at least twice in $1990 .^{81}{ }^{82}$ At the first of these meetings the Secretary of Health and Welfare ominously spelt out her position: "the industry would be heavily regulated although it was recognised to be part of society" ${ }^{\prime \prime}{ }^{83}$ The industry documents recounting these two meetings are notably subdued in tone. There was almost a sense of resignation to the negotiations, 
with the intensity that characterised industry's response to the release of the $\mathrm{COSH}$ report just a few years previous largely gone. This attitude was not to last long.

Included in $\mathrm{COSH}^{\prime}$ s recommendations was one pertaining to the introduction of regular tax increases on tobacco products. There was strong public support for the concept with over $80 \%$ of respondents to a COSH sponsored survey in favour of "greatly increasing cigarette (tobacco) taxation" ${ }^{84}$ Despite this popular support, the 1990 announcement of future legislative chances made no mention of tax increases. Industry was, therefore, caught off guard when, in March 1991, the Financial Secretary announced in his Budget Speech to the LegCo that:

"It has been put to me persuasively... that for health reasons a hefty increase [in tobacco excise] is now justified. So with a particular view to reducing the attractiveness of smoking to young people, I am proposing an increase of $200 \%$ in the rate of duty ${ }^{\prime \prime}{ }^{85}$

While the 1983 tax increase had been primarily financially motivated, this time the increase was directly linked to a concern for the health of young people. The industry had been dealt a double blow: a substantial increase in the price of cigarettes and a government policy specifically targeting young people. The initiative infuriated the industry: "this was nothing less than a bombshell" ${ }^{86}$ and "everyone is very, very angry and quite taken aback by the sheer scale of the blow, particularly when it was accompanied by the pious and frankly transparent 'health' reasoning advanced". ${ }^{87}$

Following a press release emphasising that it felt the proposal was "totally discriminatory", 88 the industry mounted a HK\$4million ${ }^{89}$ campaign, the most extensive lobbying and PR campaign yet undertaken by the industry. It included a public protest outside the offices of ExCo and LegCo members, a meeting with legislators, signature gathering (over 50000 collected), newspaper advertisements, letters to LegCo members, and a flood of press releases. ${ }^{87}$ Clive Turner went so far as to write to his British counterpart, Sir Robin Haydon, of the Tobacco Advisory Council, asking if he "had any advice about whether there was merit in stirring up a few whinges and protests in London, further to embarrass the top brass here" ${ }^{\prime 87}$

While the tax increase was strongly supported by the government's Health and Welfare branch, ${ }^{90}$ speeches given in the Chamber following the Secretary of Finance's address show that the proposal did not have the complete support of LegCo members. Many, according to the Hong Kong Economic Journal, considered the tax to be unfair to lower income groups and in contravention of HK's free economy. ${ }^{91}$ Other members had more personal reasons for opposing the increase. LegCo member Cheong Kam-Chuen was, for example, a director of BAT (HK) at the time. ${ }^{92}$

In a replay of the "phony way to show sincerity" remark from 1973, the chair of the ATC suggested a longer term strategy to his directors:

\section{"Could I suggest that... the industry considers doing a deal with government that we will mount a highly visible, substantial and long term campaign to discourage sub- teenage smoking in return for being left alone across a broad range of anti-smoking measures" ${ }^{\prime \prime}{ }^{79}$}

The TIHK ran with the idea. Within days of making the decision to "do a deal" the institute's chair wrote to the Secretary for Health and Welfare inviting the government to participate in its "Why not wait until you're 18 before you decide whether or not you want to smoke?" poster campaign. ${ }^{93}$ The Secretary of Health and Welfare was blunt in her reply: "we have been advised that these posters are unlikely to attain the stated objectives... under the circumstances you will wish to re-consider the distribution of these posters which we return herewith". ${ }^{94}$ The government's response was obviously not what the industry anticipated and their planned "deal" with government was not going to be attained easily.

Amid growing concern that the $200 \%$ increase would have a negative inflationary impact, it was lowered to $100 \%$ in May 1991. The revision was the first ever for an already exacted budgetary measure and industry took full credit for the action: "200\% tax increase quickly lowered to just $100 \%$ increase as a result of industry and consumer pressure". ${ }^{95}$

While disappointed at the tax revision, local tobacco control advocates were hopeful other proposed measures would now have a "greater chance of success" ${ }^{96}$ Noting the political climate of the time, Mackay observed a "degree of unease" ${ }^{\prime \prime 96}$ among some LegCo members who felt they had not "fulfilled their civic responsibilities". ${ }^{96}$ As a result, many recommended the pending package of proposals be passed as soon as possible. ${ }^{96}$

Proposed changes to the Public Health Bill were announced in 1991 and the public consultation process commenced. Not surprisingly, industry did not support the proposed changes, arguing that it was a case of "reason and fact" giving way to "dogma and grand gestures". ${ }^{97}$

This submission appears to be the industry's sole attempt to influence policy in any formal sense. The documents reveal only one other passing reference in the minutes of a January 1992 TIHK meeting where the chair "repeated his appeal to members for continued lobbying". 98 The legislation was introduced into the LegCo in 1992 and came into effect that same year.

Even tighter tobacco control measures were debated and introduced in the 12 months leading up to the hand over of HK to China. Industry crafted its tactics to maximise this unique historical event in three different ways: appealing to compliance with the Bill of Rights, ${ }^{* 100}$ calling for adherence to "the implied understanding" between the UK and the PRC that "no radical new laws" will be enacted before 1997, ${ }^{100}$ and arguing that "this is not the time to be curtailing commercial freedom" given the "many truly pressing items on the legislative agenda prior to $1997 " .{ }^{100}$

The industry's approach to what they considered to be a "very extreme and... unworkable" ${ }^{\prime 101}$ piece of legislation was specifically directed at the legislative process, particularly the Bills Committee. Before the committee's hearings industry made 16 separate submissions (see Fung ${ }^{102}$ and Thomas ${ }^{103}$ for examples). They made a further 15 presentations countering opponents' claims once the hearings were completed. ${ }^{104}$ Each submission had to be copied 21 times and prepared in both English and Chinese. ${ }^{104}$ In addition industry identified, prepared Q\&As for, and trained over 40 people who appeared before the Bills Committee for, or in support of industry positions. $^{104}$

Mackay and Hedley document four complaints of misrepresentation levelled against the industry including one from the British Department of Health and another from the Norwegian Minister of Health. ${ }^{105}$ In describing the lead up to the Bill's passage through the LegCo, Mackay describes the period as:

* The Bill of Rights was an ordinance designed to ensure Hong Kong continued to be a "free society where the rights of the individual, press freedom and freedom of expression are guaranteed." 
"...a real battle and a half. What happens is the tobacco industry lobbies. They lobby governments, they lobby the media. They buy up full page ads in the newspapers. They misrepresent data. They bring their lawyers, their executives. They make representations to government. They several times threatened to sue the Hong Kong government if this law went through... it is very intimidating to a government to be threatened to be sued by the tobacco industry". 106

Two bills (the Smoking (Public Health) (Amendment) (No. 2) Bill 1997 and a Private Members' Bill forwarded by Dr Leong Che-hung) were debated in the LegCo in what was considered a "last gasp attempt" $t^{\prime 101}$ to ban tobacco advertising before the hand over. Following the second reading of the government's bill, Che-hung, satisfied with the government's bill, withdrew his. ${ }^{107}$ The legislation was signed off on 26 June 1997 by Patten in what was to be his final week as Governor. ${ }^{107}$

Under the new legislation designated non-smoking areas were expanded to include supermarkets, banks, department stores, and shopping malls; advertising in printed publications was prohibited as of 31 December 1999; virtually all display advertisements were banned including outdoor signs and in-store display advertisements; internet advertisements for tobacco products were prohibited; packets of less than 20 sticks were prohibited; maximum tar content was lowered from $20 \mathrm{mg}$ to $17 \mathrm{mg}$; sale of cigarettes through vending machines was prohibited. ${ }^{108}$ However, corporate sponsorship (that is, use of the company name) was not considered to be advertising and was not banned. ${ }^{108}$ Similarly, the use of a tobacco brand in association with any product other than tobacco as the sponsor of an event was not deemed to be a tobacco advertisement and was permitted to the extent that "it falls outside the definition of "tobacco advertisement"". ${ }^{108}$

\section{DISCUSSION}

Throughout the 1970s the tobacco industry had three significant wins over the government's attempts to introduce modest tobacco control measures. The pivotal tactic employed by the industry was its use of a voluntary agreement on advertising. Their quid pro quo for this self-described "phony" gesture of goodwill was to leverage weakening of the Colony's first public health warning posters and deferring legislation on advertising for another five years. The success of the voluntary code strategy in pre-empting legislation is well recognised. ${ }^{109} 110$

Given that industry had noted that the "government believes that voluntary concessions and restrictions by the industry itself is [sic] far more preferable to legislation", ${ }^{33}$ it seems likely the government was very aware of what it was doing. The limited commitment to tobacco control by the government at that time may have provided a win-win for both parties: industry appeared to be cooperative and willing to oblige government; government appeared to be minimally active, thus going some way to appeasing local anti-smoking activists.

The documents from the 1970s repeatedly refer to government's lack of commitment to tobacco control and government officials were apparently not backward in admitting as much to industry representatives. Clearly, when there is no political interest to withstand industry's tactics to thwart government initiatives, industry will succeed.

The situation changed significantly in the 1980s and 1990s when, despite its cache of tactics, the industry had only one substantial win-the 1991 reduction in cigarette taxes. The strategy responsible for this success was an extensive industry financed lobbying and public relations campaign. While this strategy worked in favour of the industry on this

\section{What this paper adds}

The tobacco industry has long sought to influence governments as they seek to impose tobacco control measures. The various tactics and strategies employed are well documented.

For the first time the strategies of the transnational tobacco companies based in Hong Kong to delay and frustrate the government's policymaking process have been identified and analysed. The strategies are not necessarily country specific. They can (and have been) duplicated in other nations. An appreciation of industry's tactics can assist policymakers in other nations to understand better the opposition they may encounter as they move towards introducing tobacco control measures in their own countries.

occasion, the technique per se did not always guarantee success. The PR/lobbying campaign organised in 1989 to oppose the $\mathrm{COSH}$ recommendations was, for example, more intense and protracted than the 1991 campaign, yet its success was limited.

The industry's paltry record of only one win throughout the 1980 s and 1990s contrasts sharply with its outstanding record of success throughout the 1970s.

The turning point appears to have occurred in the early 1980s. In 1982 the HK government adopted an anti-smoking policy and set about using its legislative power to discourage smoking. It would appear that once a policy decision had been made legislators had the resolve to proceed with tighter tobacco control measures despite the persistent stalling and manipulative tactics of the industry. This was not the case in the 1970s when, despite the sweeping recommendations of the Ad Hoc Committee on Smoking and Health, the government decided against legislative reform. By the 1980s and on into the 1990s, political will had developed to the degree that it was largely responsible for the introduction of tightening tobacco controls.

At least three major factors contributed to the development of this political will throughout the 1980s and '90s. The first factor was the development of an active tobacco control lobby in the Colony. In 1982 HK was a country where the "antismoking lobby... [was] largely anonymous, unidentifiable, entirely unrepresentative and unaccountable"111 and "the anti-smoking campaign... lack[ed] real seriousness and longterm viability" ${ }^{58}$ Within a decade this situation had changed to such an extent that HK was described, in 1994, as having "a highly active and sophisticated anti-smoking network". ${ }^{12}$ Key activists including Judith Mackay, Director, Asian Consultancy on Tobacco Control and, from the University of Hong Kong's Department of Community Medicine, Tai Hing Lam and Anthony Hedley. The role of the Department of Community Medicine was particularly influential. Its staff were responsible for the publication of a number of articles in academic, peer review journals ${ }^{113-115}$ as well as reports prepared for government agencies such as the Environmental Protection Department. ${ }^{116}$

The second contributing factor was that of public opinion. From 1988 to 1997 a number of public opinion surveys were published by COSH and the University of Hong Kong's high profile Department of Community Medicine. Issues surveyed ranged from smoke-free restaurants ${ }^{117}{ }^{118}$ and bans on tobacco advertisements and sponsorship ${ }^{119}$ to proposed legislative changes ${ }^{84}$ and control of smoking. ${ }^{120}$ Each of these surveys strongly supported increased tobacco control measures. The impact of these publications cannot be overlooked. It has been noted that the results of public opinion surveys can have a "major" influence on government policy ${ }^{121}$ as they 
"reassure" government that tobacco control actions may win votes. ${ }^{121}$

The role played by $\mathrm{COSH}$ in generating and sustaining political will was substantial. Its research programme produced not only the public opinion surveys referred to above but a number of other reports, two of which had a particular emphasis on youth. ${ }^{122}{ }^{123}$ At the time, HK was one of the few Asian nations to have a statutory body dedicated to tobacco control, established and financed by the government.

Over and above these general factors a number of very specific occurrences have been identified as impacting on at least two pieces of legislation. In the lead up to the introduction of the 1983 legislation increasing numbers of deaths from lung cancer and death and injury through fire accidents caused by careless smoking have been identified as being influential. ${ }^{45}$ Two international events have been identified as helping in the introduction of the 1997 legislation: the announcement by Britain's Labour government of its intent to ban tobacco promotion, and the US settlement agreement. ${ }^{105}$

Given the growing political sensitivity towards tobacco control which grew out of this range of factors, the reversal of the 1991 tax increase is perplexing. The Financial Secretary's proposal was made against a backdrop of numerous other tobacco control measures which had successfully passed through the same Chamber. This particular one was, however, not favoured by numerous LegCo members who feared a backlash from their constituency. Without the full support of the LegCo, this initiative was destined to fail. The lowering of the tax just months after its introduction may have had as much to do with the political agendas of certain members of the LegCo as industry interference.

\section{Conclusion}

Mackay contends that "information on tobacco control measures taken by neighbouring governments cannot only reassure but also stimulate a government to take similar action". ${ }^{121}$ The HK case study therefore provides important lessons to other nations facing intense pressure from industry over tobacco control. The industry's modus operandi is to block, modify, delay and disrupt the policymaking process and pending legislation. It is abundantly resourced in its ambitions. However, nations are not powerless. When political will is strong, they can, as did HK, rise above the pressure and introduce and enforce policies and laws that protect their children from the impact of cigarette advertising, provide smoke-free environments, and warn those who persist in smoking of its dangers by confronting them with health warnings every time they open a pack. The tables can be turned: industry itself can be successfully thwarted and disrupted.

The legacy of the industry's largely unsuccessful efforts in HK nonetheless must be considered against the situation that may have prevailed had they not used their delaying and oppositional tactics. HK litigants suffering from tobacco caused disease may benefit from citing the many documents we have located, to construct a case that, had the industry not behaved thus, HK smokers from the 1970s to the 1990s may well have been persuaded to quit smoking earlier by more swiftly enacted government efforts.

\section{ACKNOWLEDGEMENTS}

The research reported in this paper was supported by a grant from the US National Institutes of Health (2001-2005 \# R01 CA87110-01Al), and by the National Health \& Medical Research Council (Australia) \#153857.

The authors wish to thank Ms Fiona Byrne, information manager for the Australian and Asian tobacco documents project, for her willing assistance with document searches and information management; Dr
Judith Mackay for her helpful comments on an early draft of this paper; and the reviewers for their constructive feedback.

\section{Authors' affiliations}

J Knight, S Chapman, School of Public Health, University of Sydney, Sydney, NSW, Australia

\section{REFERENCES}

1 Yeoh E. Publicly-funded bodies organizing activities with tobacco companies. Hong Kong: SAR Legislative Council, 2001:1873.

2 Hong Kong Council on Smoking and Health. Tobacco Control - Smoking prevalence in Hong Kong, http://www.info.gov.hk/hkcosh/en_main.htm [Accessed 4 Nov 2003].

3 Falconer M. Re: Smoking \& health in Hong Kong. 20 Jul 1976. Philip Morris. Bates No. 2024950032. http://legacy.library.ucsf.edu/tid/zrb46e00.

4 British American Tobacco Company Limited. BATCo Asia/Pacific review. May 1993. British American Tobacco. Bates No. 500045965/6050. http:// tobaccodocuments.org/guildford_misc/500045965-6050.html [Accessed 19 Aug 2002].

5 Osborne S. HK neon. 13 Jul 1993. British American Tobacco. Bates No. 500199474. http://tobacco.health.usyd.edu.au/tds/BAT500199474 [Accessed 27 May 2003].

6 Neuman M, Bitton A, Glantz S. Tobacco industry strategies for influencing European Community tobacco advertising legislation. Lancet 2002;359:1323-30.

7 Barnoya J, Glantz S. Tobacco industry success in preventing regulation of secondhand smoke in Latin America: the "Latin Project". Tobacco Control 2002;11:305-14.

8 Gilmore A, Nolte $E$, McKee $M$, et al. Continuing influence on tobacco industry in Germany. Lancet 2002;360: 1255.

9 Chapman S, Charter S. "Avoid health warnings on all tobacco products for just as long as we can": a history of Australian tobacco industry efforts to avoid, delay and dilute health warnings on cigarettes. Tobacco Control 2003;12(suppl III):iii13-22.

10 Chitanondh $\mathrm{H}$. The passage of tobacco control laws: Thai Davids versus transnational tobacco Goliaths. Bangkok: Thailand Health Promotion Institute, 2000.

11 Szilagyi T, Chapman S. Tobacco industry efforts to keep cigarettes affordable: a case study from Hungary. Cent Eur J Public Health 2003;11:223-8.

12 Assunta M, Chapman S. A mire of highly subjective and ineffective voluntary guidelines: tobacco industry efforts to thwart tobacco control in Malaysia. Tobacco Control 2004;13(suppl II):ii43-50.

13 Bialous S, Fox B, Glantz S. Tobacco industry allegations of "illegal" lobby and state tobacco control. Am J Public Health 2001;91:62-7.

14 Givel M, Glantz S. Tobacco lobby political influence on US state legislatures in the 1990s. Tobacco Control 2001;10:124-24.

15 Tobacco Institute of Hong Kong Limited. SRH smoking survey shows overwhelming support for status quo on smoking and cigarette advertising. [Paper for agenda item 3 of 67 th meeting of directors]. 10 Jun 1988. Philip Morris. Bates No. 2504002557/2562. http://legacy.library.ucsf.edu/tid/ oiw32e00.

16 Turner C. Tobacco: the battle for social acceptance. Speech given to the Sixth World Tobacco Exhibition \& Symposium, 22-25 October 1990. 25 Oct 1990. R.J. Reynolds. Bates No. $511970081 / 0100$. http:// legacy.library.ucsf.edu/tid/mfk43d00.

17 Rekart P. Corporate Affairs meeting. 18 Dec 1989. Philip Morris. Bates No. 2504042075/2078. http://legacy.library.ucsf.edu/tid/qnw19e00.

18 Winokur M. [Memo to A. Whist]. 29 Jun 1987. Philip Morris. Bates No. 2504046630. http://legacy.library.ucsf.edu/tid/mkx32e00.

19 Hong Kong Council on Smoking and Health. Annual report, 2000-2001. Hong Kong: Hong Kong Council on Smoking and Health, 2001.

20 Thompson J. Smoking and health - Hong Kong [Letter to A. Lyon]. 3 Dec 1976. R.J. Reynolds. Bates No. 500539686/9688. http:// legacy.library.ucsf.edu/tid/fre79d00.

21 Falconer M. The question of smoking \& health in Hong Kong. 29 Nov 1972. Philip Morris. Bates No. 2073422469/2470. http:// legacy.library.ucsf.edu/tid/vif95c00

22 Paul H. British-American Tobacco Company (Hong Kong) Limited. [Letter to M. Falconer]. 30 Jan 1973. Philip Morris. Bates No. 2024950105/0106. http://legacy.library.ucsf.edu/tid/urb46e00.

23 Hung S. Smoking \& health meeting. 14 Feb 1973. Philip Morris. Bates No. 2024950089/0098. http://legacy.library.ucsf.edu/tid/owq24e00.

24 Philip Morris Asia (Incorporated). Notes on a meeting held between the Tobacco Industry Committee and a Government Ad Hoc Committee on Cigarette Smoking held on Wednesday, February 21 1973, in the Executive Council Chamber Government Building, Hong Kong. 22 Feb 1973. Philip Morris. Bates No. 2024950084/0088. http://legacy.library.ucsf.edu/tid/ nwq24e00.

25 Tobacco Industry Hong Kong. Notes on tobacco industry meeting held on Saturday 17th February 1973 at 256 Gloucester Road. 17 Feb 1973. Philip Morris. Bates No. 2073422453/2455. http://legacy.library.ucsf.edu/tid/ pif95c00.

26 Tobacco Industry Hong Kong. "Some suggestions" for the industry's approach on the smoking health issue. Feb 1973. Philip Morris. Bates No. 2073422442/2446. http://legacy.library.ucsf.edu/tid/lif95c00. 
27 Tobacco Industry Hong Kong. Some questions which the Ad Hoc Committee on Smoking \& Health might wish to ask. Feb 1973. Philip Morris. Bates No. 2073422447. http://legacy.library.ucsf.edu/tid/mif95c00

28 Tobacco Industry Hong Kong. Notes on suggested opening remarks by the industry representatives at the meeting taking place on 21 st February with the members of the Ad Hoc Committee on Cigarette Smoking. 17 Feb 1973. Philip Morris. Bates No. 2073422448/2451. http:// legacy. library.ucsf.edu/tid/nif95c00.

29 Paul H. British-American Tobacco Company (Hong Kong) Limited. [Letter to T. Rice]. 22 Mar 1973. Philip Morris. Bates No. 2073422428. http:// legacy.library.ucsf.edu/tid/gif95c00.

30 Ad Hoc Committee on Cigarette Smoking Hong Kong. Report of the Ad Hoc Committee on Cigarette Smoking Hong Kong. 18 Mar 1974. Philip Morris. Bates No. 2024950036/0078. http://legacy.library.ucsf.edu/tid/ wrb46e00.

31 Paul H. British-American Tobacco Company (Hong Kong) Limited. Cigarette advertising - smoking \& health [Letter to M. Falconer]. 17 Jun 1976. Philip Morris. Bates No. 2024950033/0035. http://legacy.library.ucsf.edu/tid/ asb46e00.

32 Falconer M. A meeting to discuss "Cigarette advertising - code of practice" held at Lee Gardens Hotel on 14th July, 1976. 14 Jul 1976. Philip Morris. Bates No. 2073422318/2324. http://legacy.library.ucsf.edu/tid/ ghf95 $\mathrm{c00}$

33 Falconer M. Smoking \& health - Hong Kong. 10 Aug 1976. Philip Morris. Bates No. 2073422301/2302. http://legacy.library.ucsf.edu/tid/ fhf95000.

34 Pethebridge R. British-American Tobacco Company (Hong Kong) Limited. Voluntary code [Letter to A. Wong]. 4 Oct 1976. R.J. Reynolds. Bates No. 500539708/9709. http://legacy.library.ucsf.edu/tid/ore79d00.

35 Falconer M. Smoking \& health in Hong Kong [Memo to W. Campbell]. 21 Jan 1977. Philip Morris. Bates No. 2024950030. http:// legacy.library.ucsf.edu/tid/dsb46e00.

36 Hong Kong Committee on Cigarette Smoking and Health. Hong Kong Government. [Proposed poster: "Smoking Endangers Your Health"]. 18 Nov 1976. Philip Morris. Bates No. 2073422244. http:// legacy.library.ucsf.edu/tid/vgf95c00.

37 Bolsover M. British-American Tobacco Company (Hong Kong) Limited. [Letter to M. Morgan]. 24 Nov 1976. R.J. Reynolds. Bates No. 500539693/ 9694. http://legacy.library.ucsf.edu/tid/ire79d00.

38 Bolsover M. British-American Tobacco Company (Hong Kong) Limited. [Letter to M. Morgan]. 30 Nov 1976. R. J. Reynolds. Bates No. 500539690/ 9692. http://legacy.library.ucsf.edu/tid/hre79d00.

39 Bolsover M. British-American Tobacco Company (Hong Kong) Limited [Letter to M. Morgan]. 26 Nov 1976. R. J. Reynolds. Bates No. 500539695/ 9696. http://legacy.library.ucsf.edu/tid/jre79d00.

40 Pethebridge R. British-American Tobacco Company (Hong Kong) Limited. [Letter to A. Wong]. 1 Dec 1976. R.J. Reynolds. Bates No. 500539689. http://legacy.library.ucsf.edu/tid/gre79d00.

41 Pethebridge R. British-American Tobacco Company (Hong Kong) Limited. Summary of a meeting between B.A.T. \& Mr Eric Ho at B.A.T. on 16th February, 1977. 22 Feb 1977. R.J. Reynolds. Bates No. 500539652/9653. http://legacy.library.ucsf.edu/tid/rqe79d00.

42 Banwell H. [Letter to S. Witt]. 20 Dec 1978. R.J. Reynolds. Bates No. 500877542/7543. http://tobaccodocuments.org/bliley_rir/5008775427543.html [Accessed 28 Nov 2002].

43 Bolsover M. British-American Tobacco Company (Hong Kong) Limited. [Letter to R. Haddon]. 8 Sep 1977. R.J. Reynolds. Bates No. 503668689/ 8690. http://legacy.library.ucsf.edu/tid/kop85d00.

44 Philip Morris Asia-Pacific Incorporated. Status report on tobacco advertising ban on radio \& T.V. Dec 1988. Philip Morris. Bates No. 2504046638/ 6639. http://legacy.library.ucsf.edu/tid/okx32e00.

45 Mackay J. A speech made by Dr Judith Longstaff Mackay, a member of the government's anti-smoking steering committee, as background Information on government's anti-smoking measures in Hong Kong. 22 Jun 1983. Philip Morris. Bates No. 2504065698/5705. http://legacy.library.ucsf.edu/tid/ zhw32e00.

46 Dollisson J. 1989 2nd revised forecast presentation - corporate affairs. 15 Jun 1989. Philip Morris. Bates No. 2500101311/1323. http:// legacy.library.ucsf.edu/tid/fml19e00.

47 Winebrenner J. R.J. Reynolds Tobacco Company (Hong Kong) Limited. [Memorandum: government secretariat proposals on smoking], 23 Jun 1981. Brown \& Williamson. Bates No. 621603654/3657. http:// legacy. library.ucsf.edu/tid/uur30fo0.

48 Gould D. Government Secretariat. [Letter to J. Wisner]. 26 Jun 1981. Brown \& Williamson. Bates No. 621603658/3663. http:// legacy.library.ucsf.edu/tid/vur30f00.

49 Wisner J. Brown \& Williamson. Hong Kong government's proposed antismoking measures. 25 Jun 1981. Brown \& Williamson. Bates No. 621603651/3653. http://legacy.library.ucsf.edu/tid/tur30f00.

50 Winebrenner J. R.J. Reynolds Tobacco Company (Hong Kong). [Letter: revised drafting instructions for health warning/tar rating legislation], $6 \mathrm{Apr}$ 1982. Philip Morris. Bates No. 2504011034 . http:// legacy.library.ucsf.edu/tid/vg×32e00.

51 Winebrenner J. R J Reynolds (Hong Kong) Ltd. [Letter to G. Barnes]. 14 Aug 1981. Brown \& Williamson. Bates No. 621603634/3645. http:// legacy.library.ucsf.edu/tid/qur30fo0.

52 Mackay J, Barnes G. Effect of strong government measures against tobacco in Hong Kong. BMJ 1986;292:1435-37.

53 Barnes G. Address by G.T. Barnes, Deputy Secretary for Health and Welfare, Chairman of the Steering Committee on Anti-smoking Publicity
Campaign 1983-84. 22 Jun 1983. Philip Morris. Bates No. 2504065710/ 5712. http://legacy.library.ucsf.edu/tid/diw32e00.

54 Leung S. Speech given by Dr S.C. Leung, Senior Medical and Health Officer, General Health Unit, Medical and Health Department. 22 Jun 1983. Philip Morris. Bates No. 2504065715/5716. http://legacy.library.ucsf.edu/tid/ hiw 19e00.

55 Hong Kong Government Steering Committee on Anti-smoking. Major antismoking campaign starts today [press release]. 22 Jun 1983. Philip Morris. Bates No. 2504065717/5720. http://legacy.library.ucsf.edu/tid/ iiw $19 \mathrm{e} 00$.

56 RJ Reynolds Tobacco International. RJRTI statements regarding the Hong Kong government's Public Health Bill 1982. Jul 1982. Philip Morris. Bates No. 2504010980/0984. http://legacy.library.ucsf.edu/tid/jqv19e00.

57 Winebrenner J. R.J. Reynolds Tobacco Company (Hong Kong) Limited. [Letter to D. Tso and G. Bramley]. 29 Jul 1982. Philip Morris. Bates No. 2504010979. http://legacy.library.ucsf.edu/tid/nqv19e00.

58 Stein Associates Inc. Hong Kong: key government personalities in tobacco. 10 Dec 1983. Brown \& Williamson. Bates No. 501 104006/4011. http:// legacy.library.ucsf.edu/tid/mwf23foO.

59 British American Tobacco. Hong Kong. Nov 1983. Brown \& Williamson. Bates No. 501024785/4797. http://legacy.library.ucsf.edu/tid/tpi23f00.

60 Philip Morris. Summary international trade. Jan 1984. Philip Morris. Bates No. 2025434659/4682. http://legacy.library.ucsf.edu/tid/gqn04e00.

61 Power NC. Report of the Broadcasting Review Board. Hong Kong: Supreme Court, 198512 Aug:227.

62 INFOTAB. INFOTAB Board of Directors Meeting, Phoenix. 29 Oct 1984. R. J. Reynolds. Bates No. 503880524/0585. http://legacy.library.ucsf.edu/tid/ lkb7ld00.

63 Watson GH. Opening statement by Gordon H.D. Watson Chairman of the Tobacco Institute of Hong Kong Limited at the hearing of the Broadcasting Review Board at Urban Council Chambers, Hong Kong on 8th January 1985. 8 Jan 1985. Philip Morris. Bates No. 2504063672/3678. http:// legacy.library.ucsf.edu/tid/uzv19e00.

64 Watson GH. Closing statement by Gordon H.D. Watson Chairman of the Tobacco Institute of Hong Kong Limited at the hearing of the Broadcasting Review Board at Urban Council Chambers, Hong Kong on 8th January 1985. 8 Jan 1985. Philip Morris. Bates No. 2504063762/3764. http:// legacy.library.ucsf.edu/tid/egw32e00.

65 de Win P. Presentation by Paul de Win Director General of World Federation of Advertisers at the Hearing Meeting of the Broadcasting Review Board at Urban Council Chambers Hong Kong on 8th January 1985. 8 Jan 1985. Philip Morris. Bates No. 2504063694/3697. http:// legacy.library.ucsf.edu/tid/wzv19e00.

66 Smith G. Presentation by Mr Glen Smith, Chairman of Children's Research Unit, United Kingdom at the hearing meeting of the Broadcasting Review Board at Urban Council Chambers Hong Kong on 8th January 1985. 8 Jan 1985. Philip Morris. Bates No. 2504063698/3711. http:// legacy.library.ucsf.edu/tid/ozv19e00.

67 Dollisson J. Presentation by John Dollisson Chief Executive Officer of the Tobacco Institute of Australia Limited on Advertising and Health at the hearing meeting of the Broadcasting Review Board at Urban Council Chambers, Hong Kong on 9th January 1985. 9 Jan 1985. Philip Morris. Bates No. 2504063712/3718. http://legacy.library.ucsf.edu/tid/ pzv19e00.

68 Philip Morris. Marketing restrictions. Dec 1985. Philip Morris. Bates No 2023267434/7435. http://legacy.library.ucsf.edu/tid/agu24e00.

69 Tobacco Institute. TI infolog information services v.86, no. 11 [includes "Hong Kong tobacco ad issue heats up" from Journal of Commerce, New York]. 10 Feb 1986. Philip Morris. Bates No. 2024941723/1725. http:// legacy.library.ucsf.edu/tid/jlw23e00.

70 Philip Morris Asia Incorporated (Hong Kong). Philip Morris Asia Inc. 19861988 three year plan: preliminary review. Sep 1985. Philip Morris. Bates No. $2504011941 / 1992$. http://legacy.library.ucsf.edu/tid/blw32e00.

71 Administrative Services and Information Branch. A summary of public opinion on the Broadcasting Review Board report. Hong Kong: Administrative Services and Information Branch, 1986.

72 Tobacco Institute of Hong Kong Limited. [Letter to members of the Hong Kong Executive Council]. 24 Jun 1986. Philip Morris. Bates No. 2504064117/4120. http://legacy.library.ucsf.edu/tid/jxv19e00.

73 Fung J. HKTI AGM, February 16, 1989. 14 Feb 1990. Philip Morris. Bates No. 2504002913/2914. http://legacy.library.ucsf.edu/tid/qfw19e00.

74 Tobacco Institute of Hong Kong Limited. [Extracts from a Public Relations proposal]. May 1987. Philip Morris. Bates No. 2504002842/2843. http:// legacy.library.ucsf.edu/tid/zfw19e00.

75 Tobacco Institute of Hong Kong Limited. Response to anti-smoking proposals made by the Hong Kong Council on Smoking and Health. Jun 1989. Philip Morris. Bates No. 2504064365/4380. http://legacy.library.ucsf.edu/tid/ ohw32e00.

76 Tobacco Institute of Hong Kong Limited. Critique by Tobacco Institute of Hong Kong on Hong Kong Council on Smoking and Health (COSH) recommendations. Jun 1989. Philip Morris. Bates No. 2504064381/4386. http://legacy.library.ucsf.edu/tid/phw32e00

77 Chow B. Tobacco Institute of Hong Kong Limited. [Letter to Hong Kong Council on Smoking and Health]. 26 Jun 1989. Philip Morris. Bates No. 2504064362/4364. http://legacy.library.ucsf.edu/tid/axv19e00.

78 Tobacco Institute of Hong Kong Limited. Overall working report on consultation paper on COSH proposals. [Paper for agenda item 3 and agenda item 11 of 73rd meeting of directors]. Jul 1989. Philip Morris. Bates No. 2504002814/2819. http://legacy.library.ucsf.edu/tid/fgw19e00. 
79 Turner C. Asian Tobacco Council. [Letter to ATC directors: Hong Kong budget]. 7 Mar 1991. Philip Morris. Bates No. 2504003003/3005. http:// legacy.library.ucsf.edu/tid/qiw19e00.

80 Hong Kong Government. Hong Kong Government. Press release: government to step up anti-smoking measures. 15 Mar 1990. Tobacco Institute. Bates No. TIMN0340829/0830. http://legacy.library.ucsf.edu/ $\mathrm{tid} / \mathrm{kfq} 52 \mathrm{fOO}$.

81 Tobacco Institute of Hong Kong Limited. Minutes for the special meeting of directors held at the conference room of the Institute at 9:30 am on 24 May 1990. 24 May 1990. Philip Morris. Bates No. 2504002701/2703. http:// legacy.library.ucsf.edu/tid/rgw19e00.

82 Tobacco Institute of Hong Kong Limited. Minutes on special meeting of directors at conference room of the institute on Tuesday, 21 st August 1990. 21 Aug 1990. Philip Morris. Bates No. 2504002696/2699. http:// legacy.library.ucsf.edu/tid/bhw19e00.

83 Tobacco Institute of Hong Kong Limited. Notes of meeting with the Hon. Mrs Elizabeth Wong, Secretary for Health and Welfare on Tuesday, 10th April 1990. 10 Apr 1990. Philip Morris. Bates No. 2504002704/2705. http:// legacy.library.ucsf.edu/tid/qiw32e00.

84 Donnan S, Lam T, Cheng K, et al. Hong Kong Council on Smoking and Health. A public opinion survey on proposed legislative changes relating to cigarette smoking and tobacco use in Hong Kong. 24 May 1988. R.J. Reynolds. Bates No. 507689613/9622. http://legacy.library.ucsf.edu/tid/ vsa24d00.

85 Jacobs P. Second Reading of Appropriation Bill, 1991, Official Report of Proceedings, Hong Kong Legislative Council. 1991. Hong Kong Office of the Legislative and Executive Councils, p. 38

86 Chow B. Tobacco Institute of Hong Kong Limited. The problem of smuggled cigarettes - and the battle against it. Speech given at the International Tobacco Symposium. Oct 1999. R. J. Reynolds. Bates No. 521211112/ 1118. http://legacy.library.ucsf.edu/tid/fdrO1d00.

87 Turner C. Asian Tobacco Council. [Letter to Sir Robin Haydon]. 4 Apr 1991. Philip Morris. Bates No. 2504003000/3002. http:// legacy.library.ucsf.edu/tid/piw19e00.

88 Tobacco Institute of Hong Kong Limited. Media release: tobacco tax increase unfair. Mar 1991. Philip Morris. Bates No. 2504067914. http:// legacy.library.ucsf.edu/tid/sdw32e00.

89 Tobacco Institute of Hong Kong Limited. Minutes on a special meeting of directors on Monday 29th April 1991 at 9:00am at conference room of the institute. 29 Apr 1991. Philip Morris. Bates No. 2504002867/2870. http:// legacy.library.ucsf.edu/tid/qkw32e00.

90 Lau M. Department of Health and Welfare, Hong Kong Government. Press release: higher tobacco tax can help young people, 7 Mar 1991. Philip Morris. Bates No. 2504067911/7912. http://legacy.library.ucsf.edu/tid/ qdw32e00.

91 Hong Kong Economic Journal. LegCo members cigarette tax comment. Hong Kong Economic Journal (Hong Kong) 18 Apr 1991:8.

92 Cheong K-C. Second Reading of Appropriation Bill, 1991, Official Report of Proceedings, Hong Kong Legislative Council. 1991. Hong Kong Office of the Legislative and Executive Councils, p 14.

93 Scarritt J. Tobacco Institute of Hong Kong Limited. [Letter to E. Wong]. 2 May 1991. Philip Morris. Bates No. 2504061457. http:// legacy.library.ucsf.edu/tid/tww32e00.

94 Lau E. Hong Kong Government Secretariat. [Letter to J. Scarritt]. 22 May 1991. Philip Morris. Bates No. 2504002877. http:// legacy.library.ucsf.edu/tid/skw32e00.

95 Philip Morris International. Status report on tobacco advertising ban on radio \& T.V. 17 Jun 1991. Philip Morris. Bates No. 2504107220/7265. http://legacy.library.ucsf.edu/tid/kii29e00

96 Mackay J. Press release: "A pyrrhic defeat?" 15 May 1991.

97 Scarritt J. Tobacco Institute of Hong Kong Limited. Smoking (Public Health) (Amendment) Bill 1991 [Letter to E. Tu]. 5 Nov 1991. Philip Morris. Bates No. 2504064327/4335. http://legacy.library.ucsf.edu/tid/mhw32e00.

98 Tobacco Institute of Hong Kong Limited. Minutes for the 86th meeting of the Directors on 23rd January 1992. 23 Jan 1992. Philip Morris. Bates No. 2504002888/2893. http://legacy.library.ucsf.edu/tid/rfwl9e00.

99 Suen M. Rights respected. School of International \& Public Affairs, Columbia University. Fall 1996. http://www.columbia.edu/cu/sipa/PUBS/SLANT/ FALL96/suen.html [Accessed 4 Nov 2003].

100 Baker and McKenzie. Proposed amendments to the Smoking (Public Health) Ordinance (Cap. 371). 19 Sep 1995. R. J. Reynolds. Bates No. 517151731/1732. http://legacy.library.ucsf.edu/tid/ush50d00.
101 Flint J. South China Morning Post. Bid to snuff tobacco advertising by July 31 May 1997. Philip Morris. Bates No. 2065325400. http:// legacy.library.ucsf.edu/tid/ogo63c00.

102 Fung J. Tobacco Institute of Hong Kong Limited. [Letter to Bills Committee members: Bills Committee on Smoking (Public Health) (Amendment) Bill 1997 and Smoking (Public Health) (Amendment) (No. 2) Bill 1997]. 2 Jun 1997. Philip Morris. Bates No. 2065325320/5322. http:// legacy.library.ucsf.edu/tid/dho63c00.

103 Thomas M. Tobacco Institute of Hong Kong Limited. Re the Smoking (Public Health) (Amendment) Bill 1997 and the Smoking (Public Health) (Amendment) (No. 2) Bill 1997: advice, 11 Jun 1997. Philip Morris. Bate No. 2065325323/5326. http://legacy.library.ucsf.edu/tid/eho63c00.

104 Harris D. [Internal memorandum re impending legislation]. 19 Jun 1997. Philip Morris. Bates No. 2065325314/5319. http:// legacy.library.ucsf.edu/tid/cho63c00.

105 Mackay J, Hedley A. Hong Kong bans tobacco advertising. BMJ 1997:315:7-12.

106 Multinational Monitor. Taking on tobacco imperialism: interviews with tobacco control advocates from around the world. July-Aug 1997. Philip Morris. Bates No. 2064866417/6422. http://legacy.library.ucsf.edu/tid/ lge63c00

107 Friedman M. [Internal memorandum: Smoking (Public Health) (Amendment) (No. 2) Bill 1997]. 4 Jul 1997. Philip Morris. Bates No. 2065325236. http://legacy.library.ucsf.edu/tid/uho63c00.

108 Baker and McKenzie. Executive Summary: Smoking (Public Health) (Amendment) (No. 2) Ordinance 1997 passed by the Legislative Council on June 24, 1997. 25 Jun 1997. Philip Morris. Bates No. 2065325252/5253. http://legacy.library.ucsf.edu/tid/tgo63c00.

109 Daube M. Voluntary agreements: designed to fail. Tobacco Control 1993;2:183-4.

110 Saloojee Y, Dagli E. Tobacco industry tactics for resisting public policy in health. Bull World Health Organ 2000;78:902-10.

111 British and American Tobacco Co. (HK) Limited. Cigarette smoking and health [issues briefing paper]. May 1982. British American Tobacco (Non. MSA). http://tobacco.health.usyd.edu.au/tds/BAT_MIS_00001. [Accessed 4 Nov 2003].

112 Albert D. [Fax to J. Robinson]. 12 Apr 1994. R.J. Reynolds. Bates No. 512051448/1449. http://legacy.library.ucsf.edu/tid/hbg43d00.

113 Peters J, Hedley A, Lam T, et al. Factors influencing smoking behaviour in Hong Kong primary schoolchildren: targets for prevention. Asia Pac J Public Health 1995;8:102-8.

114 Peters J, Hedley A, Lam T, et al. A comprehensive study of smoking in primary school children in Hong Kong: implications for prevention. J Epidemiol Community Health 1997;51:239-45.

115 Peters J, Hedley A, Wong C, et al. Effects of an ambient air pollution intervention and environmental tobacco smoke on children's respiratory health in Hong Kong. Int J Epidemiol 1996;25:821-8.

116 Hedley A, Peters J, Lam T. Air pollution and respiratory health in primary school children in Hong Kong, 1989-1992. Hong Kong: Department of Community Medicine, University of Hong Kong, 1993:311.

117 Lam T, Chung S, Tam E, et al. Public opinion on smoke-free restaurants and experience of exposure to environmental tobacco smoke (ETS) in restaurants. Hong Kong: $\mathrm{COSH}, 1995$ Oct.

118 Lam T, Chung S, Tam E, et al. Public opinion on smoke-free restaurants and experience to exposure to environmental tobacco smoke (ETS) in restaurants. Hong Kong: Department of Community Medicine, University of Hong Kong, 1997 Nov (HSRC Report \#1).

119 Lam T, Chung S, Hedley A, et al. Public opinion on banning of tobacco advertisements and sponsorship. Hong Kong: Department of Community Medicine, University of Hong Kong, 1996 Feb.

120 Cheng K, Hedley A, Lam T, et al. A public opinion survey on measures related to the control of smoking in Hong Kong. Hong Kong: Hong Kong Council on Smoking and Health, 1993.

121 Mackay J. The politics of tobacco. Hong Kong Med J 1998;4:41 1-14.

122 Lam T, Chung S, Wong C, et al. The youth smoking and health survey 1994, Report no 1. Youth smoking, health and tobacco promotion. Hong Kong: Hong Kong Council on Smoking and Health, Nov 1994.

123 Lam T, Chung S, Wong C, et al. The youth smoking and health survey 1994, Report no 2. Youth smoking: knowledge, attitudes, smoking in schools and families and symptoms due to passive smoking, Hong Kong:Hong Kong Council on Smoking and Health, 1995 Mar. 